Article Type: Research Paper

\title{
Analysis Factors of Willingness to Pay for Halal Labelled Cosmetics on Non-Muslim Community in Yogyakarta
}

\author{
Husnaa Winny Listyarini ${ }^{1}$ and Lilies Setiartiti ${ }^{1}$
}

\begin{abstract}
This research aims to examine how product knowledge, promotion, consumers' awareness, purchase frequency, and income influence on Willingness to Pay (WTP) for halal labelled cosmetics on non-Muslim community in Yogyakarta. This research used primary data with total 100 respondents by purposive sampling method. In addition, the analysis tool in this research are descriptive statistics, Contingent Valuation Method (CVM) which being used to predict willingness to pay, and multiple regression model on SPSS 20 as data analysis program. The result of this research shows that consumers' awareness, purchase frequency, and income are positively and significantly influencing Willingness to Pay (WTP). And also the WTP value obtained for facial wash is Rp43.750, facial powder is Rp74.420, body wash is Rp31.670, toothpaste is Rp20.610, shampoo is Rp21.230, and body mist is Rp78.310.
\end{abstract}

AFFILIATION:

${ }^{1}$ Department of Economics, Faculty of Economics and Business, Universitas Muhammadiyah Yogyakarta, Yogyakarta, Indonesia.

*CORRESPONDENCE:

husnaa.winny@gmail.com

THIS ARTICLE IS AVALILABLE IN:

http://journal.umy.ac.id/index.php/jerss

DOI: $10.18196 /$ jerss.040118

CITATION:

Listyarini, H. W., \& Setiartiti, L. (2020). Analysis Factors of Willingness to Pay for Halal Labelled Cosmetics on Non-Muslim Community in Yogyakarta. Journal of Economics Research and Social Sciences, 4(1), 44-58.

\section{Introduction}

Globalization is the widespread influence of culture and science throughout the world. Normally, globalization is synonymous with both technological and science, and also in the field of communication. Progress in information technology allows international news to be known to the entire world in seconds. Globalization is a phenomenon that is inevitable, arguably globalization is something that will definitely happen. But in addition to providing economic benefits, it also brings many implications for many aspects of human life which ultimately make people adapt to the changes that occur (Paulus Rudolf, 2014). This caused a shift in lifestyle, as an example of the entry of Western culture into Eastern cultural life through the internet. This can cause Easterners to follow the Western lifestyle. In this case, according to Suneki (2012), globalization is considered as a process where events, decisions and activities in other parts of the world can affect individuals or communities in other parts of the world.

The growth of the Muslim population in countries that are predominantly Muslim and where Islam has become a minority in the world in recent years has significantly increased (Rosita, 2018). The Muslim population is the second largest population and the fastest growing religion globally in 2015 and is expected to offer more opportunities for companies operating in this market by 2030 when it reaches $26 \%$ of the global population. Due 


\section{Listyarini \& Setiartiti \\ Analysis Factors of Willingness to Pay for Halal Labelled Cosmetics ...}

to the growth of the Muslim population that has increased significantly globally this is what causes people to be interested in understanding the behaviour of Muslim consumers and want to explore the meaning of Islam itself (Yeo, 2018). This led to the emergence of increased demand for halal products because the Muslim community wants halal products to consume.

For a Muslim, it is obligatory to consume everything that is lawful. The word Halal comes from the verb "HALLA" which means permitted, legislative, permitted, legitimized, and not prohibited. Furthermore, in chemical disciplines, anything that can dissolve, be polluted, can be transformed into liquid, decomposed. And stay away from everything that is Haram, where Haram is completely contrary to the concept of Halal, whatever, action, activities that consider "taboo, make mistakes and offend according to Islamic jurisdiction. The word Haram comes from the verb "HARRAMA" which means prohibited, prohibited and non-jurisdiction in Islam (Majid, 2015).

Lately, not only has Halal food experienced an increase in demand but also Halal cosmetics that Muslim women use daily. Halal cosmetics are cosmetics as they are commonly used in the human body which have the purpose of cleaning, beautifying, or changing appearance without changing body shape. Lately it is known that the Halal market is around $\$ 1.62$ trillion per year and is anticipated to increase to $\$ 2.47$ trillion by 2018 . The halal cosmetics market represents 7 percent of the global market with $\$ 54$ billion, and is expected to reach $\$ 80$ billion with a growth of $6.8 \%$ during the period 2014 - 2020 (Al-Hajla, 2017). The development of the Halal Cosmetics industry proves that the awareness of Muslims with halal products that enter or absorbed into the body is increasing.

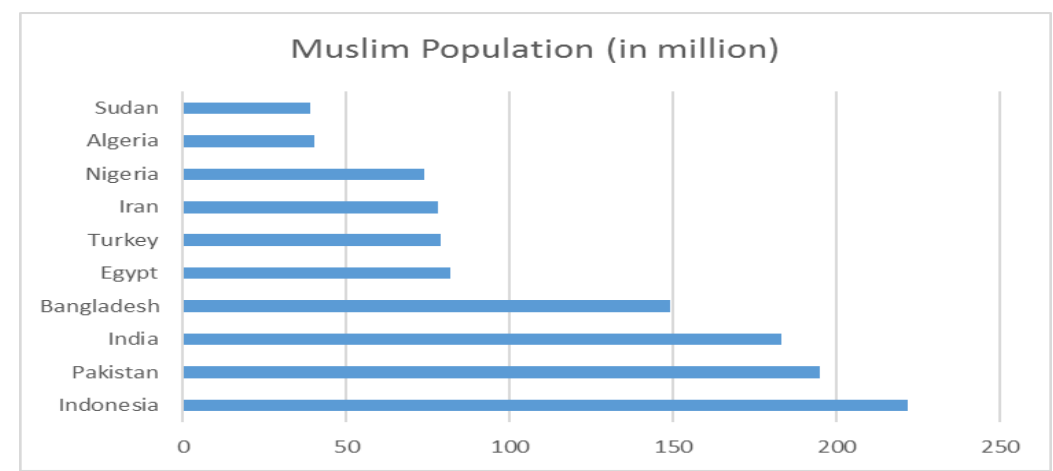

Figure 110 Largest Muslim Population in the World

The development of the halal cosmetics industry cannot be separated from the increasing Muslim population in the world. The Muslim population is the second largest population and the fastest growing religion globally in 2015 and is expected to offer more opportunities for companies operating in this market by 2030 when it reaches $26 \%$ of the global population (Yeo, 2018). The Muslim population in Indonesia ranks first with the largest population in the world with approximately 222,000 million Muslims and is followed by Pakistan with a population of around 195,000 million Muslims. 


\section{Listyarini \& Setiartiti \\ Analysis Factors of Willingness to Pay for Halal Labelled Cosmetics ...}

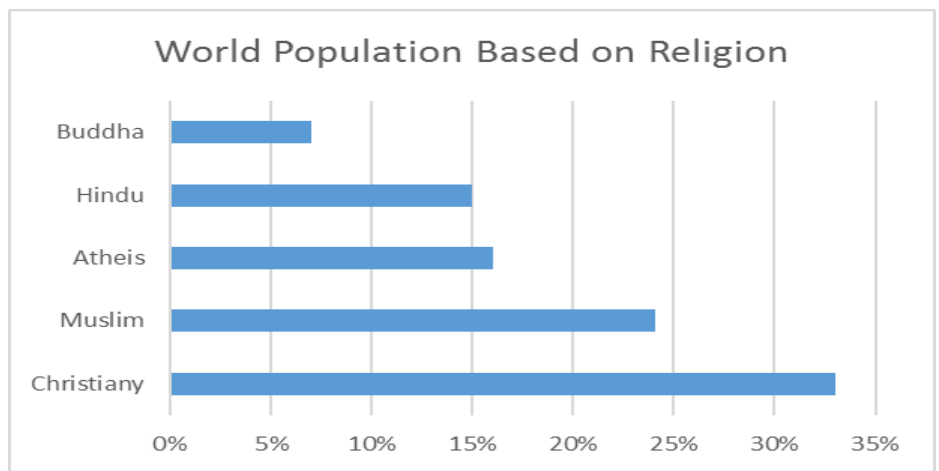

Figure 2 World Population Based on Religion

Based on figure 2, Christiany is the first largest populalation in the world. Means found 2.2 billion Christians (32\% of the world population), 1.6 billion Muslims (23\%), 1 billion Hindus (15\%), almost 500 million Buddhists (7\%) and 14 million Jews (0,2\%) worldwide in 2010. This could be an opportunities that Halal cosmetics isn't only focus to Muslim community but also all religion in the whole world because halal labelled cosmetics can be enjoyed by all people with all religious backgrounds.

The beauty industry market in Indonesia is not only entered by domestic players but also many foreign players who enter the beauty market in Indonesia. Many beauty brands are traded in Indonesia, the most popular local brand is Wardah. While Maybeline has attracted many consumers in Indonesia long before the local beauty brand in Indonesia dominated the market.

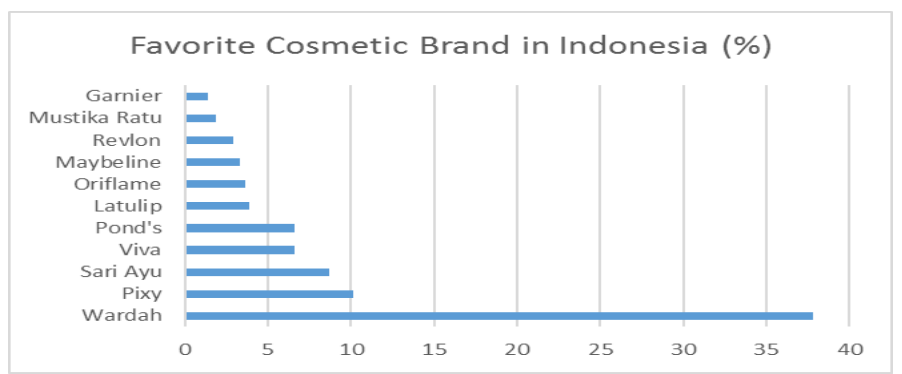

Figure 3 Women's Favourite Cosmetic Survey in Indonesia

At first, there were not many cosmetics that included halal labels on their products. Then, in 2005 Wardah already had halal certification by LPPOM MUI and then this trend began to be followed by competitors in other Halal cosmetics markets. In the survey, not only cosmetics brands were halal but also non-Halal cosmetics such as Maybeline and Revlon. In Indonesia there are around 41 brands of beauty products that already have halal certification from the Institute for Food, Drug and Cosmetic Studies of the Indonesian Ulema Council (LPPOM MUI). This number is still relatively small when compared to the number of cosmetic products in Indonesia ranging from local brands to foreign brands.

The rise of cosmetic products today is undeniably caused by technological developments. For ordinary people, beauty products that can make bright in a short 


\author{
Listyarini \& Setiartiti \\ Analysis Factors of Willingness to Pay for Halal Labelled Cosmetics ...
}

time are the best. In fact, behind that, there are many chemicals that are harmful to the skin and also substances that are prohibited by Islamic law or haram. Chemicals such as Methyl \& Propyl \& Butyl \& Ethyl Paraben, Propylene Glycol, Triclosan, and Hydroquinone are very easy to find in the market of cosmetic products if consumers are not keen on buying. Those chemical ingredients are very dangerous because it might contain carcinogenic. While carcinogenic means any substances that cause cancer by changing deoxyribonucleic acid (DNA) in the body's cells, and this interferes with biological processes.

This study was conducted to determine how consumer's ability in purchasing halal labelled cosmetics in Yogyakarta using Contingent Valuation Method (CVM). To take a sample of this research, the author take the under graduate students in Universitas Sanata Dharma and Universitas Atma Jaya Yogyakarta. The reason behind why the author choose Universitas Kristen Duta Wacana, Universitas Sanata Dharma, and Universitas Atma Jaya Yogyakarta as a sample because location at those universities are right in the middle city of Yogyakarta. Those universities are the universities that adapt Christian principle in order to learn and study. According to Kamaruddin (2012), two locations were chosen due to its location that reflects the lifestyle of the urban and rural Muslim population. The objective of Contingent Valuation Method (CVM) is to determine the willingness to pay (WTP) of the community and a desire (willingness to accept).

In order to develop the Halal Industry especially Halal Cosmetics in Indonesia, it needs an awareness from Muslim and Non Muslim community itself to consume halal labelled cosmetics and also support from government, communities, and institutions. The halal cosmetics development is important to increase sales by creating beauty products with halal label as Indonesia has big Muslim population. So that the author took "Analysis Factors of Willingness to Pay for Halal Labelled Cosmetics on Non-Muslim Community in Yogyakarta (Study at Universitas Kristen Duta Wacana, Universitas Sanata Dharma and Universitas Atma Jaya Yogyakarta, Special Region of Yogyakarta)"

\title{
Research Method
}

The subject of this research is student who study in Universitas Kristen Duta Wacana, Universitas Sanata Dharma, and Universitas Atma Jaya Yogyakarta. Those universities are based on Christian principle in order to learn and teach.

The types of data that used in this research is primary data. Which primary data is an original data or the new data that obtained or collected directly by the author on $11^{\text {th }}$ of March 2019 until $21^{\text {st }}$ of March 2019. The primary data in this study obtain by spreading the questionnaire using Google Form.

The sampling technique that used in this research is purposive sampling method. Purposive sampling method is a sampling techniques that considers several requirements for the source of data taken. The author used this method because there 
were reasons like the limitation of time, cost, and also energy. There are several requirements needed in order to take a sample, as follows:

1. Non-Muslim

2. Women ( $16-30$ years old)

3. Actively using halal labelled cosmetics in daily life

4. Take a study in Universitas Kristen Duta Wacana, Universitas SanataDharma, and Universitas Atma Jaya Yogyakarta.

Because there is no information about the exact number of students in Universitas Kristen Duta Wacana, Universitas Sanata Dharma, and Universitas Atma Jaya Yogyakarta are not known yet, then the expected number of students during the year of research using adaptive expectation where number of students in 2017 is the same as students in 2018. Determination of the sample using adaptive expectation in Zahroh (2016), namely:

$$
n=\frac{N}{1+N(e)^{2}}
$$

Where:

$\mathrm{n} \quad=$ number of samples to be studied

$\mathrm{N} \quad=$ number of students

e = per cent leeway carefully situations due to lack of sampling error is still tolerated (set at $10 \%)$.

Based on Bureau of Cooperation and Public Relations from selected universities, the total student in Universitas Kristen Duta Wacana is 5.000, the total student in Universitas Sanata Dharma is 10.728 , and the total student in Universitas Atma Jaya Yogyakarta is 11.107. So the total student from those three universities are 26.835 . Based on the information, the author could calculate the total sample needed for this research by using Slovin formula:

$$
\begin{gathered}
n=\frac{26.835}{1+26.835(10 \%)^{2}} \\
n=\frac{26.835}{269,35} \\
n=99,6 \\
n=100
\end{gathered}
$$

This result obtained from the Slovin formula, the number of respondent needed is 100 from the total population of those three universities.

This research used several independent variables namely product knowledge, consumers' awareness, purchase frequency, promotion, and income. While the dependent variable in this research is respondent's willingness to pay. Those variables are taken based on previous studies which serve as reference in this research. The 
research used the regression estimation technique of multiple linear regression with SPSS v. 21 . Multiple linear regression is used to test two or more independent variable (explanatory) against the dependent variable. The regression model used in this research is as follows:

$$
W T P=\beta_{0}+\beta_{1} \text { Knowledge }+\beta_{2} \text { Promotion }+\beta_{3} \text { Aware }+\beta_{4} \text { Purfreq }+\beta_{5} \text { Inc }+e
$$

$\begin{array}{ll}\text { Where: } & \\ \text { WTP } & =\text { Willingness to Pay } \\ \beta_{0} & =\text { Intercept } \\ \beta_{1} \ldots \beta_{6} & =\text { Regression Coefficient } \\ \text { Knowledge } & =\text { Knowledge of Product } \\ \text { Promotion } & =\text { Promotion of Product } \\ \text { Aware } & =\text { Consumers' Awareness } \\ \text { Purfreq } & =\text { Purchase Frequency } \\ \text { Inc } & =\text { Income } \\ e & =\text { Error Term }\end{array}$

\section{Result and Discussion}

\section{A. Analysis of Willingness to Pay}

The approach taken with the CVM analysis tool in this study was used to determine the value of respondents' WTP for halal labelled cosmetics. The result of implementing CVM are as follows:

\section{Setting up the Hypothetical Market}

Based on market hypotheses that have been built at the time of research, namely: "Since 2005, cosmetic products that highlight the brand image as halal cosmetic products have started to be in great demand by the public. To get the halal logo in the cosmetic packaging, cosmetic companies must pass a series of halal certification by LPPOM MUI. At present, circulating cosmetics are vulnerable to containing ingredients that are not halal and also dangerous which should be watched out for. The use of cosmetics with ingredients that are not halal (lard, pig collagen, and all its derivatives) and dangerous (mercury, paraben, triclosin, etc.) in a long period of time can harm and damage the skin so it is feared can cause cancer."

\section{Obtaining Bids}

The technique used to obtain the WTP value is an open ended question, which is done by giving an open question to the respondent about the value to be paid. Respondents will answer directly what is the maximum WTP value for halal labelled cosmetics. Which in this research the category of cosmetics consist of skincare, make up, body $\&$ oral care, hair care, and perfume. 


\section{Estimate the Mean of WTP}

The estimation of respondents' WTP (EWTP) average value is calculated based on the data of distribution of respondents' WTP using the EWTP formula.

$$
E W T P=\sum_{I=1}^{n} W i
$$

Where:

$$
\begin{array}{ll}
\text { EWTP } & \text { : estimate mean of WTP } \\
\text { Wi } & \text { : the value of WTP to-i } \\
\mathrm{n} & \text { : total respondent } \\
\mathrm{I} & \text { : respondent to-I that willing to pay }(=1,2, \ldots . \mathrm{n})
\end{array}
$$

Table 1 Distribution of WTP

\begin{tabular}{llll}
\hline No & Product & EWTP & TWTP \\
\hline 1 & Face Wash & Rp43.750 & Rp1.130.587.500 \\
2 & Face Powder & Rp74.420 & Rp1.923.161.640 \\
3 & Body Wash & Rp31.670 & Rp818.416.140 \\
4 & Toothpaste & Rp20.610 & Rp532.603.620 \\
5 & Shampoo & Rp21.230 & Rp548.625.660 \\
6 & Body Mist & Rp78.310 & Rp2.023.687.020 \\
TOTAL MEAN & & Rp44.998 & Rp1.162.846.930 \\
\hline
\end{tabular}

\section{Estimate Bid Curve}

The respondent's WTP curve is based on the WTP value of the respondents to the number of respondents who choose the WTP value.

\section{Aggregating Data}

Adding data is a process where the mean value obtained from step three is converted to the population in question using the formula:

$$
T W T P=\sum_{t=0}^{n} W T P i P
$$

Where:
TWTP $=$ Total WTP
WTPi $=$ WTP individual sample to- $\mathrm{i}$
$\mathrm{P} \quad=$ Population 


\section{B. Quality Data Test}

\section{Multicollineary Test}

The purpose of the multicollinearity test in this study was to examine whether the regression model found a correlation (strong relationship) between independent variables. To determine the absence or presence of multicollineary in this regression model, it may by looking at the value of Variance Inflation Factor (VIF) and Tolerance, as if $\mathrm{VIF}<10,00$ and the tolerance value $>0,10$ so it means there no multicollinearity.

Table 2 Value of Tolerance and VIF

\begin{tabular}{ccc} 
Instrument & Collinearity Statistics & \\
& Tolerance & VIF \\
\hline PK & 0,750 & 1,334 \\
PR & 0,837 & 1,195 \\
CA & 0,790 & 1,266 \\
PF & 0,815 & 1,228 \\
INC & 0,867 & 1,153 \\
\hline
\end{tabular}

From Variance Inflation Factor (VIF) it shows that there is no independent variables that have VIF value $<10,00$ so it means there is no multicollinearity between independent variables in regression model.

\section{Heteroscedasticity Test}

Heterocedasticity test is part of the classic assumption test in regression analysis which aims to test whether in the regression model there is an inequality of variance from residual values one observation to another observation is fixed, it is called homoscedasticity. However, if the variance of the residual value is one observation to another observation is different then it is called heteroscedasticity. A good regression model shouldn't occur heterocesdasticity.

To determine the presence or absence of heteroscedasticity in the regression model is to perform the Glejser test. Decision making in heteroscedasticity test using Glejser test is a significance value (Sig.) Greater than 0.05 , so the conclusion is that there is no heteroscedasticity in the regression model.

Table 3 Glejser Test

\begin{tabular}{|ccc|}
\hline Instrument & $\mathrm{t}$ & Sig. \\
\hline PK & $-1,920$ & 0,058 \\
PR & $-1,874$ & 0,064 \\
CA & 1,010 & 0,315 \\
PF & $-0,146$ & 0,884 \\
INC & 1,030 & 0,306 \\
\hline
\end{tabular}

It shows that the value of significance from all independent variables are greater than 0,05 . So it means that there is no heteroscedasticity in this regression model. 


\section{Normality Test}

The normality test aims to test whether the data used in the study is normally distributed or not. Good data should be normally distributed data. The basis of decision making in the normality test is if the significance value (Sig.) is greater than 0.05 then the research data is normally distributed.

Table 4 Normality Test

\begin{tabular}{cc} 
Statistics & Unstandardized Residual \\
\hline Kolmogorov-Smienov Z & 0,851 \\
Asymp. Sig (2-tailed) & 0,464 \\
\hline
\end{tabular}

From the table 4 it shows the result of normality test. From the result, the value of Asymp. Sig (2-tailed) is 0,464 it means the value is greater than 0,05 which means the residual is normally distributed.

\section{Regression Estimation Result}

Regression analysis is a model that use in this research and the model in this research is formulated with SPSS v. 21 as follows:

$$
\text { WTP }=\beta_{0}+\beta_{1} \text { Knowledge }+\beta_{2} \text { Promotion }+\beta_{3} \text { Aware }+\beta_{4} \text { Purfreq }+\beta_{5} \operatorname{lnc}+e
$$

Where:

$\begin{array}{ll}\text { WTP } & =\text { Willingness to Pay } \\ \beta_{0} & =\text { Intercept } \\ \beta_{1 \ldots \beta_{6}} & =\text { Regression coefficient } \\ \text { Knowledge } & =\text { Product Knowledge } \\ \text { Promotion } & =\text { Promotion of product } \\ \text { Aware } & =\text { Consumers' awareness } \\ \text { Purfreq } & =\text { Purchase frequency } \\ \text { Inc } & =\text { Income } \\ e & =\text { Error term }\end{array}$

Table 5 Regression Model

\begin{tabular}{|c|c|c|c|c|}
\hline Model & Definition & Standardized Coefficients & $\mathrm{t}$ & Sig. \\
\hline (Constant) & & & $-2,651$ & 0,009 \\
\hline PK & Product Knowledge & 0,014 & 0,170 & 0,866 \\
\hline$P R$ & Promotion & $-0,020$ & $-0,253$ & 0,800 \\
\hline CA & Consumers' Awareness & 0,192 & 2,490 & 0,015 \\
\hline $\mathrm{PF}$ & Purchase Frequency & 0,619 & 8,135 & 0,000 \\
\hline INC & Income & 0,167 & 2,285 & 0,025 \\
\hline R-square & & \multicolumn{3}{|c|}{0,531} \\
\hline F-stat & & \multicolumn{3}{|c|}{21,299} \\
\hline Prob F-stat & & \multicolumn{3}{|c|}{0,000} \\
\hline
\end{tabular}




\author{
Listyarini \& Setiartiti \\ Analysis Factors of Willingness to Pay for Halal Labelled Cosmetics ...
}

\title{
D. T Test (Variable Interpretation)
}

\section{Product Knowledge}

Based on the degree of freedom (df) 100-5-1 and the significance is 5 percent ( $\alpha=0.05$ ), then the $t$ table obtained 1,986. From table 5 , it shows that the value of $t$ value of knowledge product is $0,286(0,286<1,986)$ and the significance value is $0,775(0,775>$ $0,05)$. So the null hypothesis $(\mathrm{Ho})$ is accepted and the alternative hypothesis $(\mathrm{Ha})$ is rejected, so it means that product knowledge is significantly not influence the willingness to pay for halal labelled cosmetics.

\section{Promotion}

Based on the degree of freedom (df) 100-5-1 and the significance is 5 percent ( $\alpha=0.05$ ), then the $t$ table obtained 1,986 . From table 5 , it shows that the value of $t$ value of promotion is $0,033(0,033<1,986)$ and the significance value is $0,974(0,974>0,05)$. So the null hypothesis $(\mathrm{Ho})$ is accepted and the alternative hypothesis $(\mathrm{Ha})$ is rejected, so it means that promotion is significantly not influence the willingness to pay for halal labelled cosmetics.

\section{Consumers' Awareness}

Based on the degree of freedom (df) 100-5-1 and the significance is 5 percent ( $\alpha=0.05$ ), then the $t$ table obtained 1,986. From table 5 , it shows that the value of $t$ value of consumers' awareness is $2,490(2,490>1,986)$ and the significance value is $0,015(0,015$ $<0,05)$. So the null hypothesis $(\mathrm{Ho})$ is rejected and the alternative hypothesis $(\mathrm{Ha})$ is accepted, so it means that consumers' awareness is significantly influence the willingness to pay for halal labelled cosmetics. Table 5 explains about positive and significant relationship between consumers' awareness variable and Willingness to Pay (WTP). Means that when the awareness from consumers increase, so it will increase the Willingness to Pay (WTP) of halal labelled cosmetics with assumption the others variables are constant.

\section{Purchase Frequency}

Based on the degree of freedom (df) 100-5-1 and the significance is 5 percent ( $\alpha=0.05$ ), then the t table obtained 1,986. From table 5 , it shows that the value of $t$ value of purchase frequency is $7,485(7,485>1,986)$ and the significance value is $0,000(0,000>$ $0,05)$. So the null hypothesis $(\mathrm{Ho})$ is rejected and the alternative hypothesis $(\mathrm{Ha})$ is accepted, so it means that purchase frequency is significantly influence the willingness to pay for halal labelled cosmetics. Table 5 explains about positive and significant relationship between purchase frequency variable and Willingness to Pay (WTP). Means that when the consumers purchased the halal labelled cosmetics more often, so it will increase the Willingness to Pay (WTP) of halal labelled cosmetics with assumption the others variables are constant. 


\section{Income}

Based on the degree of freedom (df) 100-5-1 and the significance is 5 percent ( $\alpha=0.05$ ), then the $t$ table obtained 1,986 . From table 5 , it shows that the value of $t$ value of income is $2,285(2,285>1,986)$ and the significance value is $0,025(0,025>0,05)$. So the null hypothesis $(\mathrm{Ho})$ is rejected and the alternative hypothesis $(\mathrm{Ha})$ is accepted, so it means that income is significantly influence the willingness to pay for halal labelled cosmetics. Table 5 explains about positive and significant relationship between income variable and Willingness to Pay (WTP). Means that when the income of consumers increase, so it will increase the Willingness to Pay (WTP) of halal labelled cosmetics with assumption the others variables are constant.

\section{E. F Test}

Based on the degree of freedom (df) 100-5-1 and the significance is 5 percent ( $\alpha=0.05$ ), then the $F_{\text {table }}$ obtained 2,311. From table 5 , it shows that the value of $F_{\text {value }}$ is 21,299 and the value of probability is 0,000 . To decide whether $\mathrm{Ha}$ is rejected or accepted there is several criteria:

- Ho is accepted and $\mathrm{Ha}$ is rejected if $\mathrm{F}_{\text {value }}<\mathrm{F}_{\text {table }}$ or the significance $>0,05$

- Ho is rejected and $\mathrm{Ha}$ is accepted if $\mathrm{F}_{\text {value }}>\mathrm{F}_{\text {table }}$ or the significance $<0,05$

From criteria it can be decided that the null hypothesis (Ho) is rejected and the alternative hypothesis $(\mathrm{Ha})$ is accepted. Because the $\mathrm{F}_{\text {value }}$ from table 5 is $21,299(21,299$ $>2,311)$ then the probability value is $0,000(0,000<0,05)$. It means that consumers' awareness, purchase frequency, and income are influence willingness to pay for halal labelled cosmetics.

\section{F. $\mathbf{R}^{2}$ Test}

The value of $R^{2}$ is useful for predicting and seeing how much the influence of the variable $X$ is given simultaneously to variable $Y$. it shows that the value of $R^{2}$ is 0,531 means purchase frequency influence willingness to pay for halal labelled cosmetics as much as $53,1 \%$ and the other $46,9 \%$ influence by another factors outside from this research.

\section{Discussion}

\section{The Influence Product Knowledge on Willingness to Pay}

The first hypothesis of this research is product knowledge significantly influence willingness to pay for halal labelled cosmetics on non-Muslim community in Yogyakarta. Based on primary data that has been processed, the result is product knowledge not significantly influence willingness to pay for halal labelled cosmetics on non-Muslim community. It may be because the respondents in this research are non-Muslim so they didn't take a big concern about the halal cosmetics. And also, product knowledge is not 


\author{
Listyarini \& Setiartiti \\ Analysis Factors of Willingness to Pay for Halal Labelled Cosmetics ...
}

only the consumers know about product characteristic and the visual of product, but also product knowledge including the consequences of using product, value of satisfaction to be achieved by using product, and also to know the quality of product. Means that consumers not only familiar with several halal labelled cosmetics product but also should know the ingredient in the product.

\title{
2. The Influence Promotion on Willingness to Pay
}

The second hypothesis of this research is promotion significantly influence willingness to pay for halal labelled cosmetics on non-Muslim community in Yogyakarta. Based on primary data that has been processed, the result is promotion not significantly influence willingness to pay for halal labelled cosmetics on non-Muslim community. Refer to Kotler and Armstrong (2012), there is several ways to promote the product such as advertising, sales promotion, personal selling, public relation, and direct marketing. The assumption of why the promotion in this research did not significantly affect willingness to pay for halal labelled cosmetics is that the promotion carried out is not too focused on the "Halal" of a cosmetic product, but rather in terms of the cheap price and the visual of product itself. For example, not every halal labelled cosmetic product put "Halal" in their advertisement and did not take any concern too much on "Halal label" when the company doing any cooperation with any celebrity or even just beauty influencer in social media.

\section{The Influence Consumers' Awareness on Willingness to Pay}

The third hypothesis of this research is consumers' awareness significantly influence willingness to pay for halal labelled cosmetics on non-Muslim community in Yogyakarta. Based on the primary data processed, the result is consumers' awareness positively influence the willingness to pay for halal labelled cosmetics on non-Muslim community with assumption the other factor is constant. It means that as the consumers' awareness increase, then the willingness to pay for halal labelled cosmetics also increase.

\section{The Influence Purchase Frequency on Willingness to Pay}

The fourth hypothesis of this research is purchase frequency significantly influence willingness to pay for halal labelled cosmetics on non-Muslim community in Yogyakarta. Based on the primary data processed, the result is purchase frequency positively influence the willingness to pay for halal labelled cosmetics on non-Muslim community with assumption the other factor is constant. It means that as consumer purchase the product more often, then the willingness to pay for halal labelled cosmetics also increase.

\section{The Influence Income on Willingness to Pay}

The fifth hypothesis of this research is income significantly influence the willingness to pay for halal labelled cosmetics on non-Muslim community in Yogyakarta. Based on the 
primary data processed, the result is income positively influence the willingness to pay for halal labelled cosmetics on non-Muslim community with assumption the other factor is constant. It means that as the income increase, then the willingness to pay for halal labelled cosmetics also increase.

\section{Conclusion}

Based on analysis result and discussion, it already answers the research question about analysis willingness to pay for halal labelled cosmetics on non-Muslim in Yogyakarta. (1) The estimating mean of WTP (EWTP) of facial wash is Rp43.750, facial powder is Rp74.420, body wash is Rp31.670, toothpaste is Rp20.610, shampoo is Rp21.230, and body mist is Rp78.310. The total mean of WTP for cosmetics is Rp. 44.998. (2) Product knowledge does not significantly influence the willingness to pay for halal labelled cosmetics in Yogyakarta. Because these days, the consumers only know about the visual of product. Meanwhile the product knowledge also covers about the quality of product and the consequences of using product. (3)Promotion does not significantly influence the willingness to pay for halal labelled cosmetics in Yogyakarta. In this research, promotion indicators doesn't contain promotion tools like price discount, free sample, and buy one get one. (4) Consumers' awareness does positively and significantly influence the willingness to pay for halal labelled cosmetics in Yogyakarta. (5) Purchase frequency does positively and significantly influence the willingness to pay for halal labelled cosmetics in Yogyakarta. (7) Income does positively and significantly influence the willingness to pay for halal labelled cosmetics in Yogyakarta.

\section{References}

Adisasmito, W. (2008). Analisis Kebijakan MUI dan BPOM Dalam Labeling Obat dan Makanan. Retrieved from: https://staff.blog.ui.ac.id/wikua/files/2009/02/kebijakan-nasional-mui-dan-bpom-dalam-labeling-obat-danmakanan edited.pdf

Al-Hajla, A. (2017). Why Do People Purchase Halal Cosmetics? An Integrated Model in Saudi Arabia. International Refereed Research Journal, 7(2), 23-34.

Ali, S.,Halim, F., Ahmad, N. B. (2016). Beauty Premium and Halal Cosmetics Industry. Journal of Marketing Management and Consumer Behaviour, 1(4), 52-63.

Amelia, M. S. (2016). Pengaruh Harga dan Promosi Terhadap Proses Keputusan Pembelian pada Café Coffee Time Kopo Bandung. Undergraduate Thesis, Universitas Pasundan. Available at: http://repository.unpas.ac.id/15630/4/Bab\%202\%20SA\%20MIA

Anonymous. Top 10 Populasi Umat Muslim Terbesar di Dunia. Retrivied from: https://support.muslimpro.com/hc/id/articles/115002006087-Top-10-PopulasiUmat-Muslim-Terbesar-di-Dunia

Aziz, N. N., \& Wahab, G. (2015). Understanding of Halal Cosmetics Products: TPB Model. Research Paper, Malaysia: Universiti Tun Hussein Onn Malaysia.

Baroroh, A. (2008). Trik-Trik Analisis Statistik dengan SPSS. Jakarta: Elex Media Komputiondo.

Basuki, A. T., \& Yuliadi I. (2015). Ekonometrika Teori \& Aplikasi, Edisi 1. Yogyakarta: Mitra Pustaka 


\section{Listyarini \& Setiartiti \\ Analysis Factors of Willingness to Pay for Halal Labelled Cosmetics ...}

Basuki, A. T., \& Yuliadi, I. (2014). Elektronik Data Prosesing (SPSS 15 dan EVIEWS 7). Yogyakarta.

Kamaruddin, R., Iiberahim H., \& Shabudin A. (2012). Willingness to Pay for Halal Logistics: The Lifestyle Choice. Procedia Social and Behavioural Science, 8(75), 722-729.

Karimah, L. (2018). Willingness To Pay Perbaikan Kualitas Pelayanan Kereta Api Listrik (KRL) Serpong - Tanah Abang. Undergraduate Thesis, Universitas Muhammadiyah Yogyakarta. Retrieved from http://repository.umy.ac.id/handle/123456789/19813? show=full

Kumar, S., Aminin., T. A., \& Oktaviani., O. (2016). The Influence of Product Knowledge, Product Usability and Price toward Costimer Preference: (A Case of Samsung Smartphone Users in President University). Retrieved from https://www.researchgate.net/publication/323334704 The Influence of Product Knowledge Product Usability and Price toward Customer Preferences A Case O f Samsung_Smartphone Users in President_University

Majid, M. B., Sabir, I., \& Ashraf, T. (2015). Concumer Purchase Intention Towards Halal Cosmetics and Personal Care Products in Pakistan. Global Journal of Research in Business and Management, 1(1), 47-55.

Nurani, Erida, E., \& Rangkuti, A. (2017)._The Effect of Brand Image, Product Knowledge and Product Quality on Purchase Intention of Notebook with Discount Price as Moderating Variable. Journal of Business Studies and Management Review, 1(1), 26-32.

Nuriana, W. D. (2013). Analisis Willingness to Pay Terhadap Sertifikasi Halal Produk Kosmetik Wardah Pada Dua Lokasi Penjualan di Bogor. Undergraduate Thesis, Institut Pertanian Bogor. Retrieved from: https://repository.ipb.ac.id/handle/123456789/64800

Priambodo, L. H., \& Najib, M. (2014). Analisis Kesediaan Membayar (Willingness To Pay) Sayuran Organik dan Faktor-Faktor Yang Mempengaruhinya. Jurnal Manajemen dan Organisasi, 5(1), 1-14.

Putri, W. R., Samsudin M., Rianto E., \& Susilowati I. (2017). Consumers' Willingness to Pay for Halal Lalbelled Chicken Meat. Jumal Dinamika Manajemen, 8(1), 122-133.

Rochmanto, B. A. (2014). Pengaruh Pengetahuan Produk dan Norma Relegius Terhadap Sikap Konsumen Dalam Niat Mengkonsumsi Produk Makanan dan Minuman Halal. Undergraduate Thesis, Universitas Diponegoro Semarang. Retrieved from http://eprints.undip.ac.id/45181/

Rose, Lala Pradilla. (2017). Faktor-Faktor Yang Mempengaruhi Willingness To Pay Pada Pelayanan Poliklinik Spesialistik di Klinik Utama Asri Medical Centre Yogyakarta. Master Thesis, Universitas Muhammadiyah Yogyakarta. Retrieved from at:http://repository.umy.ac.id/handle/123456789/11490

Rosita, W. A. (2018). Perilaku Pembelian Kosmetik Berlabel Halal Oleh Konsumen di Yogyakarta, Undergraduate Thesis, Universitas Muhammadiyah Yogyakarta. Retrieved from :http://repository.umy.ac.id/handle/123456789/20156?show=full

Shamout, M., D. (2016). The Impact of Promotional Tools on Consumer Buying Behavior in Retail Market. International Journal of Business and Social Scince, 7(1), 75-85.

Shekhawat, P. (2016) .Halal and Herbal the Two Emerging Buzzwords in Indonesia's Cosmetics Market. Retrieved from bttp:// wmw.markplusinc.com/ halal-and-berbal-the-twoemerging-buz:words-in-indonesias-cosmetics-market/

Suneki, S. (2012). Dampak Globalisasi Terhadap Eksistensi Budaya Daerah. Jurnal Ilmiah CIVIS, 2(1), 307-321.

Swidi, A., Wie, C., Hassan, M. G., Al-Hossam, A., \& Kassim, A. B. (2010). The Mainstream Cosmetics Industry in Malaysia and the Emergence Growth, and Prospect of Halal Cosmetics. Retrieved from http://repo.uum.edu.my/2466/ 


\section{Listyarini \& Setiartiti}

Analysis Factors of Willingness to Pay for Halal Labelled Cosmetics ...

The Global Religious Landscape. The Pew Forum on Religion \& Public Life. Pew Research Center. Available at: https://www.pewforum.org/2012/12/18/global-religiouslandscape-exec/

Undang - undang Republik Indonesia, Jaminan Produk Halal, available at: https://www.hukumonline.com/pusatdata/detail/lt546b2bcb6e22d/node/34/uu-no33-tahun-2014-jaminan-produk-halal

Wang, L., Wang, J., \& Huo, X. (2019). Consumer's Willingness to Pay a Premium for Organic Fruits in China: A Double-Hurdle Analysis. International Journal of Enviromental Research and Public Health, 16(1), 126.

Yeo, B. L., Mohammed, R. N, \& Mohd, R. (2018). The Significance of Religious Value and Commitment on Costumers' Satisfaction and Retention for Halal Cosmetics Products in the Malaysia Market. International Journal of Innovation and Business Strategy, 9(1), 34-40.

Yusup, M. (2011). Analisis Pengaruh Promosi, Harga, Kualitas Produk dan Layanan Purna Jual Terhadap Keputusan Pembelian Sepeda Motor Honda (Studi Kasus pada Mahasiswa Fakultas Ekonomi Universitas Dipenogoro Semarang). Undergraduate Thesis, Universitas Diponegoro Semarang, Retrieved from http://eprints.undip.ac.id/29032/1/MUHAMMAD YUSUP_JURNAL.pdf

Zahroh, S. S. F. (2017). The Factors That Influencing Willingness To Pay The Visitors of Pangandaran Beach Ussing Contingent Valuation Method (CVM). Undergraduate Thesis, Universitas Muhammadiyah Yogyakarta. Retrieved from http://repository.umy.ac.id/handle/123456789/10490

Zailani, S., Kanapathy, K., \& Iranmanesh, M. (2016). Driver of Consumers' Willingness to Pay for Halal Logistics, Retrieved from bttps:// mmw.researchgate.net/publication/285409786 